\title{
An Overview of The Traditional Use of Sago for Sago-based Food Industry in Indonesia
}

\author{
Andi Patiware Metaragakusuma ${ }^{*}, 1$ Osozawa Katsuya ${ }^{2}$ and Hu Bai $^{2}$ \\ ${ }^{1}$ Department of Bioresource Production Science, The United Graduate School of Agricultural \\ Sciences, Ehime University, 3-5-7 Tarumi, Matsuyama, Ehime 790-8566, Japan \\ ${ }^{2}$ Department of Bioresources and Environmental Policy, Faculty of Agriculture, Ehime University, \\ 3-5-7 Tarumi, Matsuyama, Ehime 790-8566, Japan \\ Email: ap.metaragakusuma@yahoo.com*
}

\begin{abstract}
The use of sago had been practiced traditionally since ancient times by people who live in sago producing areas in Indonesia, and it had been able to gradually create sago-based food industry. As a result, sago has become an important raw material. Nevertheless, most sago-based food industry occurs naturally without an integrated comprehensive plan. The processing skills are inherited from the ancestors and handed down to the next generation continuously. In addition, there are many descriptions of the traditional way to prepare foods from sago. Surely, the wider utilization of sago can be a catalyst for rural industrial development. Thus, this paper is intended to deliver information about the diversity of traditional use of sago for sago-based food industry from all the major sago-producing areas in Indonesia in order to focus the farmers ', entrepreneurs', and Indonesian government's attention. It is predicted that sago demands in the future will increase. The sustainability of sago as a raw material for sago-based industry, however, will not be discussed in this paper. Further studies on that is needed
\end{abstract}

Keywords: Sago-based food Industry, Sago Palm, Sago Starch, The use of Sago.

\section{INTRODUCTION}

Sago (English) or Sagu (Indonesia and Malaysia) is the extracted starch from sago palm (Metroxylon spp) [1]. Sago has been consumed as a traditional staple food since ancient times by people who live in sago producing areas in Indonesia [2]. For traditional society, sago is not only as a major component of diet, but also has a central position in myth and ritual, which has been brought into symbolic relationship with the twins concepts of germination of plants and generation of humans [3]. Sago palm has been recognized as the oldest food plants for human being [4].

Sago has long been known and used for food industry in cottage and in home industry level [5]. Based on biology dictionary, food industry is the industry concerned with processing, preparing, preserving, distributing, and serving of foods and beverages. The utilization of sago traditionally had been able to gradually create sago-based food industry. As a result, sago has become an important raw material now. Nevertheless, most sago-based food industry occurs naturally without an integrated comprehensive plan. The skills in sago processing are inherited from the ancestors and handed down to the next generation continuously [6].

Apart from the importance of sago for sago-based food industry, sago has a big opportunity in food industry sector. This is because this sector dominates the number of micro and small industries in Indonesia by giving contribution of $35.47 \%$ (64.53\%: other industries in 22 sectors. Total $\mathrm{N}=3,505,064$ ) [7]. Therefore, the objective of this study is to deliver information about the diversity of traditional use of sago for sago-based food 
industry from all the major sago-producing areas in Indonesia in order to focus the farmers`, entrepreneurs', and Indonesian government`s attention.

\section{THE METHODOLOGY OF STUDY}

This overview study uses sources from 30 literatures namely scientific papers including journals and proceedings (53.33\%), books (26.66\%), thesis (6.66\%), annual report (3.33\%), and others (10\%) such as encyclopedia, dictionary and youtube video. Its range of published years is from 1977 to 2015.

\section{THE BENEFIT OF SAGO}

Sago has many advantages compared to other commodities [8], particularly compared to rice and wheat flour because the consumption pattern of staple food in Indonesia is dominated by rice (78.4\%) and followed by wheat flour (14.73\%), while sago ranked at sixth place $(1.07 \%)$ after cassava $(2.88 \%)$, sweet potato $(1.48 \%)$ and corn (1.38\%) [9].

Sago benefit in its compositions. It has a high carbohydrate content (84.7g per $100 \mathrm{~g}$ ), which is higher than rice $(80 \mathrm{~g}$ per $100 \mathrm{~g})$ and wheat flour (77.3g per 100g) [10]. Minister of Agriculture once said that sago as a local food has a great potential to be developed in supporting food diversification because it contains a high carbohydrate [11]. Sago also has a low calorie and fat content, which are good for diet. Its protein content is very low and free from casein and gluten, so it is good to be consumed as a non-allergic food [12]. In addition, sago is safe to be consumed by diabetic people because it does not raise blood glucose levels immediately (low glycemic index). As a resistant starch, sago can prevent the risk of constipation and colon cancer [13].

Sago benefit in its utilization. Various sago-based foods can be made, and it can give business opportunity and home industry to grow [14]. Sago even can substitute wheat flour in producing white bread, biscuit and cookie. The substitution in the range of $30 \% \sim 40 \%$ will not give any effect related to the quality of product [15], [16].

Sago has a high potency to be produced. Sago palm can produce up to 25 tons of starch per hectare per year; it is higher than other source of carbohydrate crops namely rice (6 tons), wheat (5 tons) [17]. Sago palm area in Indonesia is huge, it is about 1.28 million ha or $51.3 \%$ of the total sago area in the world [18] and its utilization is only $10 \%$ or about 128.106 ha [19].

\section{THE UTILIZATION OF SAGO}

The traditional use of sago for sago-based food industry is categorized in 6 ways: (1) sticky dough where it is considered as nasi (cooked rice) such as Papeda/ kapurung/ sinonggi, (2) roasted sago such as Sagu lempeng/ Dange/ Sagu rangi, (3) sago noodle, (4) various of snacks, (5) sago pearls, (6) and dried refining sago starch [15], [20]-[22]. These various utilizations of sago cannot be separated from its starch uniqueness. Sago is easy to gelatinize; as it requires a low temperature for gelatinization, it has a high adhesiveness and it is easy to be molded [23].

Commonly, sago is prepared by pouring a little amount of hot water into starch and stirring properly until it becomes sticky dough. The dough can be consumed with some side dishes or further processed[24],[13].

\subsection{Papeda/ Kapurung/ Sinonggi}

Papeda is a native food to Maluku and Papua, made only from fresh sago and it is considered as nasi (cooked rice) by the local people [22]. Papeda is made by mixing the starch with water until suspension is formed. Hot water is added slightly over the starch while keep stirring until the color of suspension is evenly distributed and it becomes sticky. It is served separately with side dishes namely kuah kuning or yellow fish soup, and vegetable.

Kapurung is a traditional food of Luwu, South Sulawesi. The process of making kapurung is slightly similar as papeda, however, after the suspension becomes a gel, the paste is then shaped into small chunks by using bamboo chopsticks. Paste is then mixed with fish, shrimp and vegetable in a container [15].

Sinonggi is usually referred as papeda of Southeast Sulawesi. The process of making sinonggi and the way of serving is almost similar as papeda, however, sinonggi is eaten with a mixed vegetable soup (mossonggi), which contains spinach, rounded small eggplant (palola), and other local vegetables. 
Papeda, kapurung and sinonggi had enlivened culinary world in Indonesia as a sago-based food Industry. Some restaurants had been established even in big cities such as Makassar and Jakarta. For instance, there was no Kapurung restaurant in Makassar before 1999. The number of the restaurant has increased from 1 restaurant in 1999 to 23 restaurants in 2012 [25]. Furthermore, Kapurung Restaurant does not only sell Kapurung as the main menu, but also other sago-based products such as dange, ongolongol and bagea to be offered to the consumer.

\subsection{Roasted Sago}

Roasted sago is popular especially in Eastern Part of Indonesia. It is called dange (South Sulawesi) or sagu lempeng (Maluku and Papua), and it is eaten with grilled fish or by dipping it into hot water or hot tea. Basically, HMT (Heat Moisture Application) method that is a heat treatment application on the certain moisture level of starch, is applied in the process of making roasted sago [21]. Fisherman prefers to bring roasted sago when they go to sailing due to its durability and high resistance to common damaging factors during transportation and storage. So far, there is no report about damage by spoilage, which is caused by molds and insects. Roasted sago is relatively non-hygroscopic, however, it is easy to swell quickly when it is dipped in liquid or beverage [22].

Dange is made by mixing wet and dried sago until the mixture becomes crystal, then it is put into heated mold clay, and heated again for a second. After ejected from the mold, it is allowed to cool first and then ready to be packaged [21]. Sagu lempeng is made by using wet sago. Then it is sifted twice to form crumbs and to obtain a fine starch. Starch then is ready to put into heated mold clay called forna, covered with banana leaves and allowed to be cooked for 15-20 minutes [15].

Roasted sago is also known as sagu rangi in Bogor, West Java. It is processed to become porridge by adding palm sugar and coconut milk inside. Different with dange, sagu rangi is made from dried starch by pouring water around $34-45 \%$. Starch is then put into steel plate mold and heated again for a second. After ejected from the mold, it is put under sunlight for a while and ready to be packaged [21] .

\subsection{Sago Noodle}

Noodle or Mie is the popular food, flexible and has no inferior impression. As a result, various sago-based noodle processed food can be found in Sumatera namely mie laksa, mie goreng sagu and mie tarempa [21], even, nowadays almost all sago produced in Meranti District, Riau, Sumatera, is delivered to Cirebon, West Java, to be sold for sohun glass noodle manufacture [26] with modern technology.

However, sago noodle can be made manually at home industries by using traditional equipment by local people. There are 6 stages in sago noodle processing: starch gelatinization, dough formation, molding, cooking, soaking and place for draining. In gelatinization stage, hot water and food dye are added until gel is formed, then add sago starch slightly over the gel until dough formed. At this stage, dough is ready to be molded. While molding process is running, boiled water is prepared to put molded noodle until it floats, then the noodle is set to be drained. The next process is putting noodle under running water for several hours, then place for a dry. Adding a little bit vegetable oil is needed to avoid the noodle to be sticky. At this stage, sago noodle is ready to be used as a raw material to make some sago-based noodle processed food. [21].

\subsection{Snacks (Bagea, Ongol-ongol, Cendol)}

Bagea is common name for traditional sago-based cookie, known in Maluku, Papua, and South Sulawesi with pale brown color and can be found in various forms, mostly in circle form. The other materials for making bagea are sugar, walnut, peanut, vegetable oil, cinnamon and clove powder. [27]. It is known also as bagea manado; sticks shaped sago cookie which is wrapped in sago leaves [22]. In Maluku and Papua, bagea is sometimes wrapped in banana leaves. Bagea is made by mixing starch with eggs, walnut and salt. Then it is wrapped by using sago or banana leaves. After wrapping process finish, starch is ready to be heated in a pot [15].

Ongol-ongol and cendol are traditional snack from West Java, Ongol-ongol has a brown color with small ball shape while cendol has a green color with small oval shape. Both of them has elastic texture and use brown sugar and coconut in their preparation [28]. The 
preparation of ongol-ongol is similar to papeda, but it is mixed with brown sugar, the paste is shaped into small sphere and sprinkled by coconut crumb. It is not served with fish and vegetables as papeda is served [15].

\subsection{Sago Pearls}

Sago pearl is a kind of sago-based food product with small (about $2 \mathrm{~mm}$ diameter) opaque balls and dry. It is colored naturally white, or artificially pink/red. Sago pearls is made traditionally by local society and is used for making dessert, snack and porridge. In cookpad.com, there are 45 recipes of making various products by using sago pearls [29].

Sago pearls is preserved for extended periods because it only contains $1-2 \%$ of moisture content. Traditionally, it is made from mixture of wet sago, rice bran and grated coconut. The important part of this process is left overnight of the mixture to gives sufficient time for certain microorganism, yeasts, and lactobacilli to reveal to the mixture a slightly acidic flavor and to propose carbon dioxide. The mixture is then put onto pandanus leaves, mixed properly, and starting the process of mixture forms into small balls which is sometimes assisted by addition of dried starch. Next, colorization process, and is continued to the baking process by using $1 \times 2 \mathrm{~m}$ of hearth for 20-30 minutes [30].

\subsection{Dried Refining Sago Starch}

An innovation process from wet sago can result dried starch which has smoother and whiter starch. The preparation of dried starch is done manually, it is started by leaching the wet sago with distilled water, then allow it to precipitate for 3 hours to separate water and starch. The water is then disposed manually. Next, the left starch is dried under sunlight for a couple of days. Dried starch is ready to be sieved by using 120 mesh of sieving.

Dried refining sago starch is used as a material for making cookie, pudding, bread or other starch-based product. Nowadays, it has been sold in some traditional markets, mini markets and souvenir shop. In addition, for industrial purpose, dried refining sago starch has been produced in farmer level. For instance, around 30 years ago (1985), it was done in one of the villages in South Sulawesi. The starch was successfully marketed to supply some biscuits factories in Makassar, the capital city of South Sulawesi [20]. In large scale, dried refining sago starch is also made by big manufacture in Bogor, Indonesia and it has been sold nationally.

\section{SAGO-BASED FOOD PRODUCTS IN INDONESIA}

More than 63 in total of sago-based food products are found in 21 of 33 provinces in Indonesia and some of them have been produced for food industry. Table 1 below shows sago-based products that have potency to be developed in supporting food diversification [9].

Table 1. Indonesian Sago-based Food Products

\begin{tabular}{|c|c|c|c|}
\hline No & Province & $\begin{array}{l}\text { Name of } \\
\text { food }\end{array}$ & $\begin{array}{c}\text { Raw } \\
\text { material(s) }\end{array}$ \\
\hline \multicolumn{4}{|c|}{ Sumatera Island } \\
\hline 1 & Aceh & $\begin{array}{l}\text { - Lempeng } \\
\text { ubi kayu } \\
\text { - Timpan sagu }\end{array}$ & $\begin{array}{l}\text { - Sago } \\
\text { - Sago \& } \\
\text { banana }\end{array}$ \\
\hline 2 & $\begin{array}{l}\text { West } \\
\text { Sumatera }\end{array}$ & $\begin{array}{l}\text { - Pinere } \\
\text { - Lompong } \\
\text { Sagu } \\
\end{array}$ & $\begin{array}{l}\text { - Sago } \\
\text { - Sago \& } \\
\text { Banana }\end{array}$ \\
\hline 3 & Riau Islands & $\begin{array}{l}\text { - Laksa } \\
\text { Sagu } \\
\text { - Mie Laksa } \\
\\
\text { - Kirai Sagu } \\
\text { - Mie } \\
\text { Goreng } \\
\text { Sagu } \\
\text { - Gobal } \\
\text { Sagu } \\
\text { - Mie } \\
\text { Tarempa } \\
\\
\text { - Lendod } \\
\text { - Krenas }\end{array}$ & $\begin{array}{l}\text { - Sago } \\
\text { - Sago } \\
\text { - \&Tamban } \\
\text { fish } \\
\text { - Sago } \\
\text { - Sago } \\
\text { noodles \& } \\
\text { Eggs } \\
\text { - Sago } \\
\text { - Sago } \\
\text { noodles \& } \\
\text { Eggs } \\
\text { - Sago } \\
\text { - Pearl sago }\end{array}$ \\
\hline 4 & Jambi & - Kue Satu & $\begin{array}{l}\text { - Sago \& } \\
\text { Eggs }\end{array}$ \\
\hline 5 & $\begin{array}{l}\text { South } \\
\text { Sumatera }\end{array}$ & $\begin{array}{l}\text { - Pempek } \\
\text { - Tekwan } \\
\text { - Kipo }\end{array}$ & $\begin{array}{l}- \text { Sago \& } \\
\text { mackerel } \\
\text { - Sago \& } \\
\text { mackerel } \\
\text { - Sago }\end{array}$ \\
\hline 6 & Riau & $\begin{array}{l}\text { - Sagu } \\
\text { Rendang } \\
\text { - Sagu Lemak } \\
\text { - Sagu Stick } \\
\end{array}$ & $\begin{array}{l}\text { - Sago } \\
\text { - Sago } \\
\text { - Sago } \\
\end{array}$ \\
\hline 7 & $\begin{array}{l}\text { Bangka } \\
\text { Belitung } \\
\end{array}$ & - Kericu & $\begin{array}{l}\text { - Sago, squid } \\
\text { eggs \& eggs }\end{array}$ \\
\hline \multicolumn{4}{|c|}{ Kalimantan Island } \\
\hline 8 & $\begin{array}{l}\text { West } \\
\text { Kalimantan }\end{array}$ & - Mie Sagu & $\begin{array}{l}\text { - Sago \& } \\
\text { Shrimp } \\
\end{array}$ \\
\hline 9 & $\begin{array}{l}\text { Central } \\
\text { Kalimantan }\end{array}$ & $\begin{array}{l}\text { - Papeda } \\
\text { - Sagu Goreng } \\
\text { - Talam } \\
\text { Jagung }\end{array}$ & \begin{tabular}{|l} 
- Sago \\
- Sago \\
- Sago \& corn \\
Starch
\end{tabular} \\
\hline
\end{tabular}




\begin{tabular}{|c|c|c|c|}
\hline 10 & $\begin{array}{l}\text { East } \\
\text { Kalimantan }\end{array}$ & $\begin{array}{l}\text { - Bubur } \\
\text { Gunting }\end{array}$ & - Sago \\
\hline \multicolumn{4}{|c|}{ Java Island } \\
\hline 11 & West Jawa & $\begin{array}{l}\text { - Sagu rangi* } \\
\text { - Ongol- } \\
\text { ongol* } \\
\text { - Cendol* } \\
\text { - Mie gleser* } \\
\text { - Mie leor* }\end{array}$ & $\begin{array}{l}\text { - Sago } \\
\text { - Sago, brown } \\
\text { sugar, } \\
\text { coconut } \\
\text { crumb } \\
\text { - Sago, food } \\
\text { dye } \\
\text { - Sago } \\
\text { - Sago }\end{array}$ \\
\hline \multicolumn{4}{|c|}{ Sulawesi Island } \\
\hline 12 & $\begin{array}{l}\text { South } \\
\text { Sulawesi }\end{array}$ & $\begin{array}{l}\text { - Kapurung } \\
\text { - Dange* } \\
\text { - Bagea* } \\
\text { - Sinole* } \\
\text { - Lange* } \\
\text { - Ongol- } \\
\text { ongol* } \\
\text { - Jalaure* } \\
\text { - Cakko- } \\
\text { cakko* } \\
\text { - Cendol* }\end{array}$ & $\begin{array}{l}\text { - Sago, fish, } \\
\text { chicken \& } \\
\text { peanuts } \\
\text { - Sago } \\
\text { - Sago \&palm } \\
\text { Sugar }\end{array}$ \\
\hline 13 & $\begin{array}{l}\text { Southeast } \\
\text { Sulawesi }\end{array}$ & - Sinonggi & - Sago \\
\hline 14 & $\begin{array}{l}\text { Central } \\
\text { Sulawesi }\end{array}$ & $\begin{array}{l}\text { - Papeda } \\
\text { - Kapurung } \\
\text { - Jepa }\end{array}$ & $\begin{array}{l}\text { - Sago } \\
\text { - Sago } \\
\text { - Sago }\end{array}$ \\
\hline 15 & $\begin{array}{l}\text { North } \\
\text { Sulawesi }\end{array}$ & \begin{tabular}{|l} 
- Bagea \\
Kenari*
\end{tabular} & $\begin{array}{r}\text { - Sago \& } \\
\text { walnuts }\end{array}$ \\
\hline 16 & Gorontalo & $\begin{array}{l}\text { - Ilabulo } \\
\text { - Kue Kokole } \\
\text { - Duwo } \\
\text { - Delepao } \\
\text { - Ilepao* } \\
\text { - Bagea* } \\
\end{array}$ & \begin{tabular}{|l} 
- Sago \& \\
chicken \\
liver \\
- Sago \\
- Sago \& fish \\
- Sago \& fish \\
- Sago
\end{tabular} \\
\hline \multicolumn{4}{|c|}{ NTT, Maluku and Papua Island } \\
\hline 17 & $\begin{array}{l}\text { East Nusa } \\
\text { Tenggara }\end{array}$ & - Akar Bilang & - Sago \\
\hline 18 & Maluku & $\begin{array}{l}\text { - Papeda } \\
\text { - Sagu } \\
\text { Lempeng } \\
\text { - Bagea } \\
\text { - Sinoli } \\
\text { - Buburnee* }\end{array}$ & $\begin{array}{l}\text { - Sago } \\
\text { - Sago } \\
\text { - Sago } \\
\text { - Sago } \\
\text { - Sago }\end{array}$ \\
\hline 19 & $\begin{array}{l}\text { North } \\
\text { Maluku }\end{array}$ & $\begin{array}{l}\text { - Sagu } \\
\text { lempeng } \\
\text { - Papeda } \\
\text { - Bagea kenari }\end{array}$ & $\begin{array}{l}\text { - Sago } \\
\text { - Sago } \\
\text { - Sago \& } \\
\text { walnuts }\end{array}$ \\
\hline 20 & Papua & $\begin{array}{l}\text { - Papeda } \\
\text { - Puding Sagu } \\
\text { Buah Merah } \\
\text { - Bubur } \\
\text { Kacang Sagu } \\
\text { - Buburnee* } \\
\end{array}$ & $\begin{array}{l}\text { - Sago } \\
\text { - Sago, red } \\
\text { fruit } \\
\text { \&jackfruit } \\
\text { - Sago \& } \\
\text { green beans } \\
\text { - Sago } \\
\end{array}$ \\
\hline 21 & West Papua & - Papeda & - Sago \\
\hline
\end{tabular}

Source: [9] *Compiled from many sources

\section{CONCLUSION}

The experiences of local people in consuming sago have proven that sago has wider utilization. It can give opportunity to home industry to grow, and of course indirectly can give economic impact to the farmers.

Sago becomes an important raw material for food Industry and it is predicted that demand of sago in the future will increase.

Sago-based food products, with total 63 various of products that are spread in 21 of 33 provinces Indonesia, have provided a lot of benefits, and surely has a high potency to be developed further for wider acceptance purpose, especially in processing efforts in food industry sector.

\section{REFERENCES}

[1] FAO. 2013. Regional Sago network launched across Asia and the Pacific: Greater Sago use will help to promote food security. (http://www.fao.org/asiapacific/news/detailevents/en/c/172925/). Accessed on Jun 10, 2014.

[2] M. H. Bintoro. 1999. Pemberdayaan Tanaman Sagu Sebagai Penghasil Bahan Pangan Alternatif dan Bahan Baku Industri yang Potensial dalam Rangka Ketahanan Pangan Nasional "Sago Palm Empowerment as The Source of Food Alternative and The Potential of Agro-Industry Raw Material in Acceleration National Food Security. Bogor, Indonesia: Bogor Agricultural University.

[3] R. Kenneth, J. Dennis, T. Patricia, K., R. John. D. 1978. Sago in Myth and Ritual. In Palm Sago, A Tropical Starch from Marginal Lands. (pp. 70-94). (Editor: R. Kenneth, J. Dennis, T. Patricia K., R. John. D). Honolulu: The University Press of Hawai.

[4] J. B. Avé. 1977. Sago in Insular South-East Asia: Historical aspects and contemporary use. First Int. Sago Symp. (pp. 21-30). Kuching, Malaysia

[5] P. Pangloli and Royaningsih. 1992. Pengaruh Substitusi Terigu Dengan Pati Sagu dalam Pembuatan Biskuit Marie dan Cracker "The Effects of Wheat Substitution with Sago Starch in Making Marie Biscuit and Cracker". Proceedings of National Sago Symposium 1213 Oktober 1992.

[6] L. A. R. Baka, T. Hemon, Y. B. Pasolon, Alberth. 2015. System Engineering Of Sago Agro-industry Development Using a Regional Approach. Advances in Mathematics and Statistical Sciences. (pp. 488-493). WSEAS

[7] Badan Pusat Statistik. 2015. "Central Statistic Agency. 
[8] Y. Leong, A. Karim, M.H. Norziah. 2007. Effect of Pullulanase Debranching of Sago (Metroxylon sagu) Starch at Sub Gelatinization Temperature on the Yield of Resistant Starch. Starch/Stärke, Volume: 59 page 21-page 32.

[9] Food Security Agency. 2012. Roadmap Diversifikasi Pangan 2011-2015 "Roadmap of Food Diversification 2011-2015.” 2nd ed. Jakarta: Ministry of Agriculture.

[10] Directorate of Nutrition Ministry of Health. 1979. Daftar Komposisi Bahan Makanan “Food Composition”. Jakarta, Indonesia: Bhatara Aksara.

[11]-Minister of Agriculture. 2010. Lokakarya National Sagu "National Sagu Symposium." Bogor, Indonesia.

[12]_J. H. Elder, M. Shankar, J. Shuster, D. Theriaque, S. Burns, L. Sherrill. 2006. The Gluten-Free, Casein-Free Diet in Autism: Results of A Preliminary Double Blind Clinical Trial. J. Autism Dev. Disord., Volume: 36 no. 3 page 413-page420.

[13]_A. A. Karim, A. P. L. Tie, D. M. A. Manan, I. S. M. Zaidul. 2008. Starch From The Sago (Metroxylon Sagu) Palm Tree - Properties, Prospects, and Challenges as A New Industrial Source For Food and Other Uses. Compr. Rev. Food Sci. Food Saf., Volume: 7 no. 3 page 215-page 228.

[14].N. Hayati, R. Purwanti, A. Kadir W. 2014. Preferensi Masyarakat Terhadap Makanan Berbahan Baku Sagu ( Metroxylon Sagu Rottb ) Sebagai Alternatif Sumber Karbohidrat di Kabupaten Luwu dan Luwu Utara Sulawesi Selatan ( Community Preferences Towards Sago-Based Food ( Metoxylon sagu Rottb ) as an Alternatif Carbohydrate Source in Luwu District and North Luwu District, South Sulawesi. Jurnal Penelitian Sosial dan Ekonomi Kehutanan "Journal of Forestry Social and Economics". Volume: 11 no. 1 page 82-page 90.

[15]_B. Haryanto and P. Pangloli. 1992. Potensi dan Pemanfaatan Sagu "Potency and The Utilization of Sago”. Yogyakarta: Kanisius.

[16] H. Konuma, R. Rolle, S. Boromthanarat. 2012. Adding value to underutilized food resources : substituting wheat flour with sago starch in cookie formulations. Journal of Agricultural Technology, Volume: 8 no 3 page1067-page 1077.

[17]_A. Ishizaki. 2009. Sago, an Attractive Renewable Resource which Saves Human`s Crisis of Environment and Energy. Proceedings of the 1st ASEAN Sago Symposium 29-30 Oct 2009. Kuching, Sarawak: ASAS.
[18]-_D. Pietries. 1996. Studi Mengenai Hutan Sago di Maluku "The Study About Sago Forest in Maluku”. Bogor, Indonesia: Bogor Agricultural University.

[19] Ministry of Agriculture of Republic of Indonesia. Directorat General of Estate Crops. 2015. Statistik Perkebunan Indonesia "Tree Crop Estate Statistic of Indonesia 2013-2015”. Jakarta, Indonesia.

[20] A. P. Metaragakusuma. 2015. Sago Development in South Sulawesi: Its Current Situation, New Movement and the Succesion on the Sago Culture by Small Scale Sago Farmers. Thesis. Matsuyama, Ehime: Ehime University,.

[21] Postharvest Research Center. 2003. Laporan Tahunan 2003 'Annual Report 2003. Jakarta, Indonesia.

[22] S. Wijandi. 1979. Sago and the food-energy shortagein Indonesia. Sago The Equatorial Swamp as a Natural Resource (pp. 39-42).

[23] G. Maaruf, Y. B. Che Man, B. A. Asbi, A. H. Junainah, J. F. Kennedy. 2001. Effect of water content on the gelatinisation temperature of sago starch. Carbohydr. Polym., Volume: 46 page 331-page337.

[24] M. Flach. 1979. The Sago Palm and Its Yield Potential. Kualalumpur, Malaysia: Univ. of Malaysia Pus.

[25] N. Genda. 2014. インドネシアにおける サゴヤシ の利用と今後の可能性 "The Utilization and Future Possibility of Sago in Indonesia". Thesis. Matsuyama, Ehime: Ehime University.

[26] C. T. Craig and A. K. Christian. 2015. Petlands and plantations in Sumatra, Indonesia: Complex realities for resource governence, rural development and climate change mitigation. Asia Pac. Viewp., Volume: 56 no. 1 page153-page168.

[27] Wikipedia Indonesia. 2014. Bagea (https://en.wikipedia.org/wiki/Bagea).

Accessed on October 15, 2015.

[28] Wikipedia Indonesia. 2013. Ongol-ongol. (https://id.wikipedia.org/wiki/Ongol-ongol). Accessed on October 15, 2015

[29] Cookpad. 2015. Mutiara (sagu mutiara) Resep "The recipes of pearls (sago pearls)". (https://cookpad.com/id/cari/mutiara\%20(\%20 sagu\%20mutiara\%20). Accessed on November 20, 2015.

[30] R. Kenneth, J. Dennis, T. Patricia, K., R. John. D. 1978. Traditional Extraction and Preparation of Sago. In Palm Sago. A Tropical Starch from Marginal Lands. (pp. 11-41). (Editor: R. Kenneth, J. Dennis, T. Patricia K., R. John. D). Honolulu: The University Press of Hawai. 